\title{
De Novo Synthesis and Secretion of a 36-kD Protein by Cells That Form Lupus Inclusions in Response to $\alpha$-Interferon
}

\author{
Steven A. Rich \\ Laboratory of Pathology, Wadsworth Center for Laboratories and Research, New York State Department of Health, and School of Public \\ Health, State University of New York, The University at Albany, Albany, New York 12201-0509
}

\begin{abstract}
In response to the pure recombinant human $\alpha-$ IFN, IFLrA, Raji and Daudi were the only two cell lines among 19 human lymphoblastoid cell lines tested that formed the human lupus inclusions (LI) to a high frequency. Raji, Daudi, and five other cell lines were examined for protein changes that might accompany LI formation. Their selection was based upon $T$ or B origin, association with Epstein-Barr virus, and ability to form LI. A trace protein of an estimated molecular mass of $36 \mathrm{kD}$ (p36) and an isoelectric point of 5.6 was detected on two-dimensional gels only of $\alpha$-IFN-treated Raji and Daudi cells. Gamma-IFN did not induce p36 or LI in any of these seven cell lines. In Daudi cells p36 and LI formed simultaneously in response to IFLrA, and persisted until the $\alpha$-IFN-induced death of the culture. In Raji cells, p36 and $L I$ appearance and disappearance coincided with the addition and removal of $\alpha$-IFN. Fractionation of Raji cells with nonionic-detergent buffer placed p36 with the inclusions in the cytoplasmic supernatant. With detergentfree buffer p36 and LI were distributed evenly between the nuclear and cytoplasmic fractions. Pulse-chase experiments revealed that p36 was secreted. The de novo synthesis of p36 with $\alpha$-IFN treatment was shown by labeling the cell proteins with $\left[{ }^{35} \mathrm{~S}\right]$ methionine before and after the addition of $\alpha$-IFN. These results along with previous results on the de novo synthesis of $\mathrm{LI}$ in the endoplasmic reticulum (which is involved in the processing and secretion of proteins) suggest a role for $L I$ in the synthesis and secretion of p36. (J. Clin. Invest. 1995 95:219-226.) Key words: cell differentiation • inclusion bodies • electrophoresis • lupus erythematosus $\bullet$ acquired immunodeficiency syndrome.
\end{abstract}

\section{Introduction}

Human lupus inclusions (LI) ${ }^{1}$ (1) are abnormal cytoplasmic structures that form in the cytoplasm of reticuloendothelial cells

Address correspondence to Dr. Steven A. Rich, Wadsworth Center for Laboratories and Research, New York State Department of Health, Empire State Plaza, PO Box 509, Albany, NY 12201-0509. Phone: 518474-6389; FAX: 518-474-7992. 1994.

Received for publication 28 April 1994 and in revised form 21 July

1. Abbreviations used in this paper: IFLrA, human recombinant $\alpha$-IFN A; LI, lupus inclusion; OAS, oligoadenylate synthetase; $\mathrm{p} 36,36-\mathrm{kD} \alpha$ IFN-induced protein.

The Journal of Clinical Investigation, Inc

Volume 95, January 1995, 219-226 of individuals with SLE (2) and AIDS (3). Virus-like structures, tubuloreticular inclusions and tubuloreticular structures are other names used in the literature to refer to LI. Such inclusions are not detected in the cells of healthy individuals. These inclusions are induced both in vitro and in vivo by type $I$ ( $\alpha$ and $\beta ; 1)$ but not type II $(\gamma) \operatorname{IFN}(4)$. The inclusions are known to be products of normal cells abnormally stimulated with $\alpha$ IFN as shown by their induction in peripheral blood mononuclear cells prepared from adult Red Cross blood donors (4), and from umbilical cord bloods from routine deliveries (5).

The formation of LI in SLE and AIDS is the consequence of chronic high levels of endogenous IFN in the circulation of individuals with these diseases $(6,7)$. Persistently high levels of IFN contrast sharply with the typical 24-h burst of IFN that is associated with a virus infection. The IFN in SLE and AIDS is an unusual $\alpha$-IFN that is acid-labile like $\gamma$-IFN, but that is neutralized by antibodies to $\alpha$-IFNs $(6,8)$. This unusual $\alpha$-IFN in the sera of individuals with SLE and AIDS has an extraordinary ability to induce the inclusions (8).

LI are reported to be a prognostic marker for disease progression in individuals with AIDS $(3,9)$. Induction of LI by SLE sera corresponds to the disease activities of the serum donors at the extremes of disease activity (8). Individuals with the greatest serum concentrations of IFN induce LI to the greatest frequencies, and these patients have the greatest disease activities. Individuals in remission do not have measurable levels of IFN and their sera do not induce the inclusions. Undetectable serum levels of IFN are typical of healthy individuals (8). Thus for both AIDS and SLE the chronic presence of IFN and formation of LI is associated with disease activity.

LI are de novo synthesized complexes of ribonucleoprotein and membrane with carbohydrate and no DNA (10). They form in a restricted region of the endoplasmic reticulum that makes contact with adjacent regions of the outer nuclear envelope and the Golgi apparatus (11). These results suggest that LI might function in membrane biogenesis, the trafficking of proteins to the plasma membrane or to cytoplasmic vesicles, or the processing of proteins for secretion.

Little else is known about the origin, cell function, and systemic significance of these inclusions because they have never been purified and their molecular components have never been identified and characterized (12). An inability to readily purify these inclusions is consistent with their localization in the endoplasmic reticulum, a membrane system not enclosed within a double membrane and therefore not able to be isolated in intact form (10).

Results from the current study show that an IFN-induced protein of a molecular mass of 36- $\mathrm{kD}(\mathrm{p} 36)$ and an isoelectric point of 5.6 is associated with LI. This protein provides a new avenue for investigation into the possible significance of the roles of LI and IFN in the immune-based diseases of SLE and AIDS. 


\section{Methods}

IFN preparations and titers. The purified recombinant human IFNs IFLrA (Hoffmann-La Roche, Nutley, NJ) and gamma (Genentech Inc., South San Francisco, CA) were assayed for antiviral activity on WISH cells challenged with vesicular stomatitis virus (Indiana strain) (13). Their titers are reported relative to the National Institutes of Health human IFN $\alpha$ - and $\gamma$ - standards (G023-901-527 and Gg23-901-530, respectively; kindly provided by the Antiviral Substances Program of the National Institutes of Allergy and Infectious Diseases). $1 \mathrm{U} / \mathrm{ml}$ of IFN provides $50 \%$ protection of cell monolayers.

Cell lines, culture and IFN induction. 19 human lymphoblastoid cell lines (see Table I) were grown in suspension in RPMI 1640 medium/ $10 \%$ fetal calf serum (GIBCO BRL, Gaithersburg, MD)/100 U/ml of penicillin and $100 \mu \mathrm{g} / \mathrm{ml}$ of streptomycin (14). Tissue culture flasks (Bellco Glass, Inc., Vineland, $\mathrm{NJ}$ ) were kept in a humidity-controlled incubator (Wedco, Silver Springs, MD) with a $5 \% \mathrm{CO}_{2}$ atmosphere at $37^{\circ} \mathrm{C}$. The cells were maintained in exponential growth and at $<5 \%$ nonviability by resuspension every 3 or $4 \mathrm{~d}$ in fresh medium. Cell densities were determined in duplicate on a model F cytometer (Coulter Cytometry, Hialeah, FL), and the percentage of nonviable cells was determined by trypan blue exclusion. Cells were taken from cultures at indicated times of $100 \mathrm{U} / \mathrm{ml}$ of IFLrA or $\gamma$-IFN treatment for analysis of LI, p36, and oligo-isoadenylate synthetase.

Epstein-Barr nuclear antigen assay. All 19 of the human lymphoblastoid cell lines were evaluated for Epstein-Barr nuclear antigen (15) Multi-well slides were prepared from PBS-washed cells that were fixed for $5 \mathrm{~min}$ in ice-cold methanol and acetone $(1: 1, \mathrm{vol} / \mathrm{vol})$, and air-dried. Epstein-Barr positive and negative human sera (virus testing program, Wadsworth Center for Laboratories and Research) were decomplemented and added to duplicate wells of cells. The slides were processed as described (15), mounted in $\mathrm{pH} 9$ mounting fluid, and read on a fluorescence light microscope using a X40 dry objective and X10 eyepieces.

$\left[{ }^{35} S\right]$ Methionine radiolabeling of cell and secreted proteins. Cells were washed in methionine-free RPMI 1640 media (GIBCO BRL)/ $10 \%$ dialyzed FCS. $20 \times 10^{6}$ cells were incubated for 40 min at $37^{\circ} \mathrm{C}$ in $8 \mathrm{ml}$ of medium supplemented with $25 \mu \mathrm{Ci} / \mathrm{ml}$ of $\left[{ }^{35} \mathrm{~S}\right\}$ methionine (ICN Biomedicals Inc., Irvine, CA). For the detection of secreted proteins, half of these radiolabeled cells were washed and resuspended in $4 \mathrm{ml}$ of RPMI $1640 / 0.75 \%$ FCS, incubated for $2 \mathrm{~h}$, and the supernatant was centrifuged at $100,000 \mathrm{~g}$ for $60 \mathrm{~min}$ (type 50 rotor, Beckman Instrs. Inc., Fullerton, $\mathrm{CA}$ ) before processing for two-dimensional gel analysis. For the detection of cell proteins, the remaining cells were washed and suspended in $2 \mathrm{ml}$ of RPMI 1640/10\% FCS, incubated for $5 \mathrm{~min}$, then washed and suspended in $2 \mathrm{ml}$ of serum-free RPMI 1640 before processing for two-dimensional gel analysis. Incorporated radioactivity was determined from portions of the two-dimensional gel samples. IFLrA and $\gamma$-IFN were added to the corresponding wash and incubation media as required.

Cell fractionation. $50 \times 10^{6}$ IFLrA-induced Raji cells were resuspended in $4^{\circ} \mathrm{C}$ reticulocyte standard buffer $/ 0.1 \mathrm{mM}$ phenylmethylsulfonyl fluoride with and without $0.1 \%$ Tween $40(10,16)$. After $10 \mathrm{~min}$ on ice the cells were gently vortexed until lysed. Nuclei were pelleted at $1500 \mathrm{~g}$ for $10 \mathrm{~min}$. LI were pelleted from the nuclear supernatant by a 15-min centrifugation at $8,000 \mathrm{~g}$. Nuclei and LI pellets were overlaid with glutaraldehyde for electron microscopy, and precipitated with TCA for two-dimensional gel analysis.

Electron microscope enumeration of LI. Cell samples were fixed in $3 \%$ glutaraldehyde, postfixed in osmium tetroxide, dehydrated in graded ethanol, and embedded in Epon (1). Thin $(0.25-\mu \mathrm{m})$ sections were stained with uranyl acetate and lead citrate, and examined on a 301 electron microscope (Philips Electronic Instrs. Co., Mahwah, NJ). LI frequency estimates are based on a binomial model (1). The ratio of the mean diameter of inclusions to that of whole cells is the probability (d) of observing an LI in a random thin section of a given cell that contains an LI. Factoring in the probability that an LI exists in the cell
Table I. LI Formation in Human T and B Lymphoblastoid Cell Lines

\begin{tabular}{|c|c|c|c|}
\hline Cell line & LI frequency & Cell origin & EBNA status ${ }^{\ddagger}$ \\
\hline & $\%$ & & \\
\hline Daudi & 15 & B & + \\
\hline Raji & 12 & B & + \\
\hline Raji-R $\mathbf{R}^{\S}$ & $<2$ & B & + \\
\hline U698 & $<2$ & B & - \\
\hline NC 37 & $<2$ & B & + \\
\hline Jiyoye & $<2$ & B & + \\
\hline EB-3 & $<2$ & B & + \\
\hline Namalwa & $<2$ & B & + \\
\hline SB & $<2$ & B & + \\
\hline HSB2 & $<2$ & $\mathrm{~T}$ & - \\
\hline MOLT & $<2$ & $\mathrm{~T}$ & - \\
\hline CEM & 0 & $\mathrm{~T}$ & - \\
\hline BJAB" & 0 & B & - \\
\hline BJAB/HR1K & 0 & B & + \\
\hline BJAB/B95-8" & 0 & B & + \\
\hline RAMOS & 0 & B & - \\
\hline AW RAMOS" & 0 & B & + \\
\hline LUK II** & 0 & B & - \\
\hline $8866.7 * *$ & 0 & B & - \\
\hline
\end{tabular}

* Percentage of 400 independent cell sections examined that contained an LI (see EM enumeration of LI; Methods). Cells were cultured for $72 \mathrm{~h}$ in the presence of $100 \mathrm{U} / \mathrm{ml}$ of IFLrA. ${ }^{\ddagger}$ The measured presence $(+)$ or absence $(-)$ of Epstein-Barr Virus Nuclear Antigen was determined by the complement-fixation fluorescence assay (see EBNA Assay, Methods). ${ }^{\S}$ Raji-R was derived from Raji cells by continuous growth in the presence of bromodeoxyuridine to select cells that were resistant to the toxic effects of bromodeoxyuridine. "BJAB/HR1K and BJAB/ B95-8 were derived from the EBV-negative cell line BJAB by transformation in vitro with the Epstein-Barr viruses HR1K and B95-8, respectively. 'AW RAMOS was derived from the EBV-negative cell line RAMOS by infection in culture with the Epstein-Barr virus AW. ** LUK II and 8866.7 produced $\alpha$-IFN constitutively.

$(P)$ gives a probability of observing $\mathrm{LI}$ in a cell population $\left(P^{*}\right)$, or $P^{*}=d P$. For each sample 400 independent cell sections were examined. Thin sections separated by greater than the $20-\mu \mathrm{m}$ diameter of the cells were used to approximate random sampling. A $10 \%$ frequency $\left(P^{*}\right)$ (40 out of 400 independent cell sections) is consistent with one 2.0- $\mu \mathrm{m}$ diameter LI $(P=1)$ per cell of a $20-\mu \mathrm{m}$ diameter $(d=2.0$ $\mu \mathrm{m} / 20 \mu \mathrm{m}=10 \%$ ). The corresponding $95 \%$ confidence interval of LI frequencies for 400 independent cell sections is $7-13 \%$ (1).

Two-dimensional polyacrylamide gel electrophoresis. Aliquots of $10^{7}$ cells ( $1 \mathrm{mg}$ of protein) were washed in serum-free RPMI 1640 , precipitated with $10 \% \mathrm{TCA}$ (wt/vol), and extracted twice with ethyl ether, dried, and processed for isoelectric focusing (17). Two-dimensional polyacrylamide gel protein maps were obtained $(17,18)$ with $200 \mu \mathrm{l}$ of sample run on 3-mm inner diameter and $12-\mathrm{cm}$ long focusing cylinders. Cylinders were focused at $400 \mathrm{~V}$ for $16 \mathrm{~h}$, and then at 800 $\mathrm{V}$ for $1 \mathrm{~h}$ in a Polyanalyst gel electrophoresis apparatus (HAAKE, Inc., Paramus, $\mathrm{NJ}$ ) using $0.1 \mathrm{M}$ phosphoric acid (anode) and $0.1 \mathrm{M}$ sodium hydroxide (cathode). Equilibrated cylinders ( $5 \mathrm{ml}$ of $3 \%$ ( wt/vol) SDS, $6.2 \%$ (wt/vol) $\beta$-mercaptoethanol, $62.5 \mathrm{mM}$ Tris, $\mathrm{pH} 6.8$ for $15 \mathrm{~min}$ at $4^{\circ} \mathrm{C}$ ) were attached to $0.75-\mathrm{mm}$ thick SDS slabs with a minimal vol of $1 \%$ agarose. Low molecular weight markers (Pharmacia LKB Biotechnology Inc., Piscataway, NJ) were used for size calibration, and $\mathrm{pH}$ measurement was obtained with $0.5-\mathrm{cm}$ slices of duplicate focused 

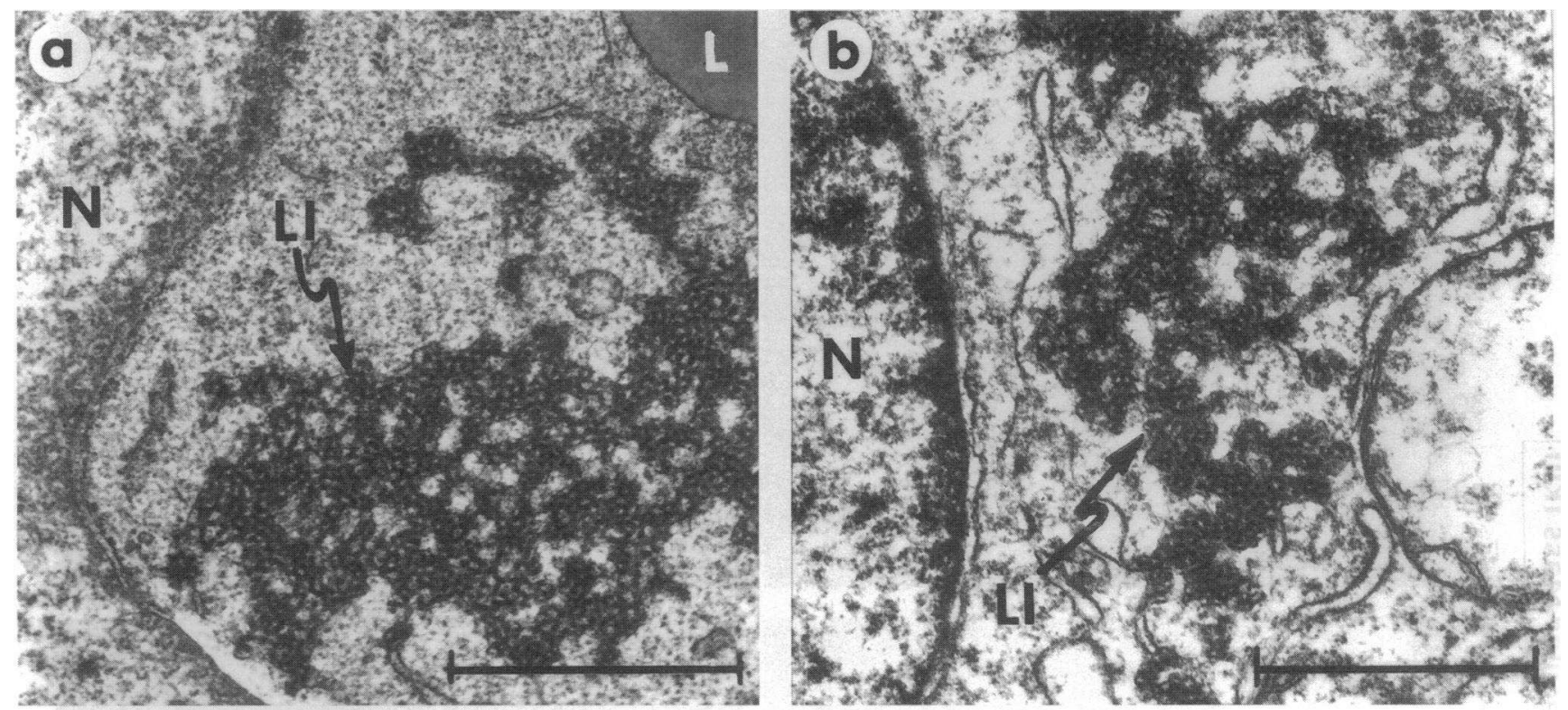

Figure 1. Electron micrographs of lupus inclusions (LI) in thin sections $(0.1 \mu \mathrm{m})$ of $(a)$ Daudi and $(b)$ Raji cells that were cultured for $72 \mathrm{~h}$ with $100 \mathrm{U} / \mathrm{ml}$ of IFLrA. N, nucleus; L, lipid granule. LI are seen to be complexes of membrane with tubular structures of 20-28 $\mathrm{nm}$ diameter. The sections were stained with uranyl acetate and lead citrate, and examined in a Philips 301 electron microscope. Bar $=1 \mu \mathrm{m}$.

cylinders equilibrated in $1 \mathrm{ml}$ of water. The vertical slab apparatus (SE500; Hoefer Sci. Instrs., San Francisco, CA) was run at $10^{\circ} \mathrm{C}$ and $110 \mathrm{~V}$ for $30 \mathrm{~min}$, followed by $220 \mathrm{~V}$ until the bromphenol blue dye marker reached the bottom of the slab $(\sim 3 \mathrm{~h})$. Slab gels were stained with either Coomassie brilliant blue or silver (Bio Rad Laboratories, Richmond, CA). For fluorography slab gels were fixed for $45 \mathrm{~min}$ in $50 \%$ methanol $/ 10 \%$ acetic acid, soaked in water for $30 \mathrm{~min}$, and equilibrated in $1 \mathrm{M}$ sodium salicylate for an hour (19), before drying and processing (20).

Oligoadenylate synthetase (OAS) assay. Cell pellets washed in PBS were overlaid with $500 \mu \mathrm{l}$ of Triton X-100 lysis buffer $(0.5 \% \mathrm{wt} / \mathrm{vol}$ Triton X-100, $20 \mathrm{mM}$ Hepes, $120 \mathrm{mM} \mathrm{KCl}, 5 \mathrm{mM}$ magnesium acetate, $7 \mathrm{mM} \beta$-mercaptoethanol, $10 \% \mathrm{wt} / \mathrm{vol}$ glycerol ) and vortexed $(5,21)$. Supernatant $(100 \mu \mathrm{l})$ after $2 \mathrm{~min}$ of centrifugation at $15,600 \mathrm{~g}$ was adsorbed to poly (rI) : (rC)-agarose beads (Pharmacia LKB Biotechnology Inc., Piscataway, NJ). The picomoles of ATP incorporated into isoadenylate oligomers were calculated from the cpm in the eluted products from the alumina column (Sigma Chemical Co., St. Louis, MO) $(5,21)$ and the cpm of the $\left.\alpha{ }^{32} \mathrm{P}\right]$ ATP (Amersham, Arlington Heights, IL) added to the adsorbed agarose beads (5).

\section{Results}

IFLrA induction of lupus inclusions in human lymphoblastoid cells. 19 human lymphoblastoid cell lines were evaluated for their ability to form lupus inclusions in response to the purified recombinant leukocyte IFN, IFLrA (Table I). Before IFN treatment no inclusions were seen in any of the cell lines. With $\alpha$ IFN treatment two of the cell lines, Daudi (Fig. $1 a$ ) and Raji (Fig. $1 b$ ), formed inclusions at a cell frequency of $>10 \%$ of cell sections, nine at a frequency $<2 \%$, and in the remaining eight lines no inclusions were detected. LUK II and 8866.7 constitutively produce $\alpha$-IFN. Neither of these cell lines formed LI either before or after the addition of IFLrA. Both Daudi and Raji cells formed LI when grown in media conditioned by these cells, which showed that the IFN they produced had the biologi- cal activity to induce LI. LI formation was not restricted to B or $\mathrm{T}$ cell origin, or infection with Epstein-Barr virus (Table I, EBNA status ).

Two-dimensional protein gel analyses of IFN-induced cells. The high LI frequencies in Daudi and Raji cells suggested that LI-associated IFLrA-induced proteins would also be elevated. Comparison of two-dimensional protein gels revealed only one IFLrA-induced protein that was common to both IFLrA-treated cells (Fig. 2, $a$ and $c$; Daudi and Raji, respectively) that was not present in the untreated cells (Fig. 2, $b$ and $d$; Daudi and Raji, respectively). This protein, termed p36, has an estimated size of $36 \mathrm{kD}$ and an isoelectric point of 5.6.

Five additional cell lines (Table II) chosen from those listed in Table I were also examined by two-dimensional gels for p36 protein. Selection of these cell lines was based on their B (SB, RAMOS, and AW RAMOS) and T (HSB2 and MOLT) cell origins, their association with Epstein-Barr virus ( $\mathrm{SB}$ and $\mathrm{AW}$ RAMOS) and their formation of LI, although at the low frequencies of $<2 \%$ (SB, HSB2, and MOLT). However, p36 was not detected in any of these other cell lines either before or after IFN treatment with $100 \mathrm{U} / \mathrm{ml}$ of IFLrA.

Gamma-IFN did not induce p36 or LI in any of the cell lines examined, including Daudi and Raji cells. OAS activation indicated that all seven of these cell lines were responsive to both $\alpha$ - and $\gamma$-IFNs. For all of these cell lines OAS activation was less with $\gamma$-IFN than with IFLrA. Daudi and Raji did not always show activation with $\gamma$-IFN, and when activation occurred, it was always $<$ twofold in contrast with a $>$ twofold and up to fivefold (RAMOS) activation in the other five lines. OAS activation with IFLrA was shown to be transient, rising rapidly by $18-24 \mathrm{~h}$ and falling to almost untreated levels by $144 \mathrm{~h}$.

Time course of IFLrA induction of lupus inclusions and p36 protein in Daudi and Raji cells. In Daudi cells $\alpha$-IFN induced p36 protein by $6 \mathrm{~h}$ and LI by $12 \mathrm{~h}$ (Fig. $3 \mathrm{a}$ ). Daudi cells began 


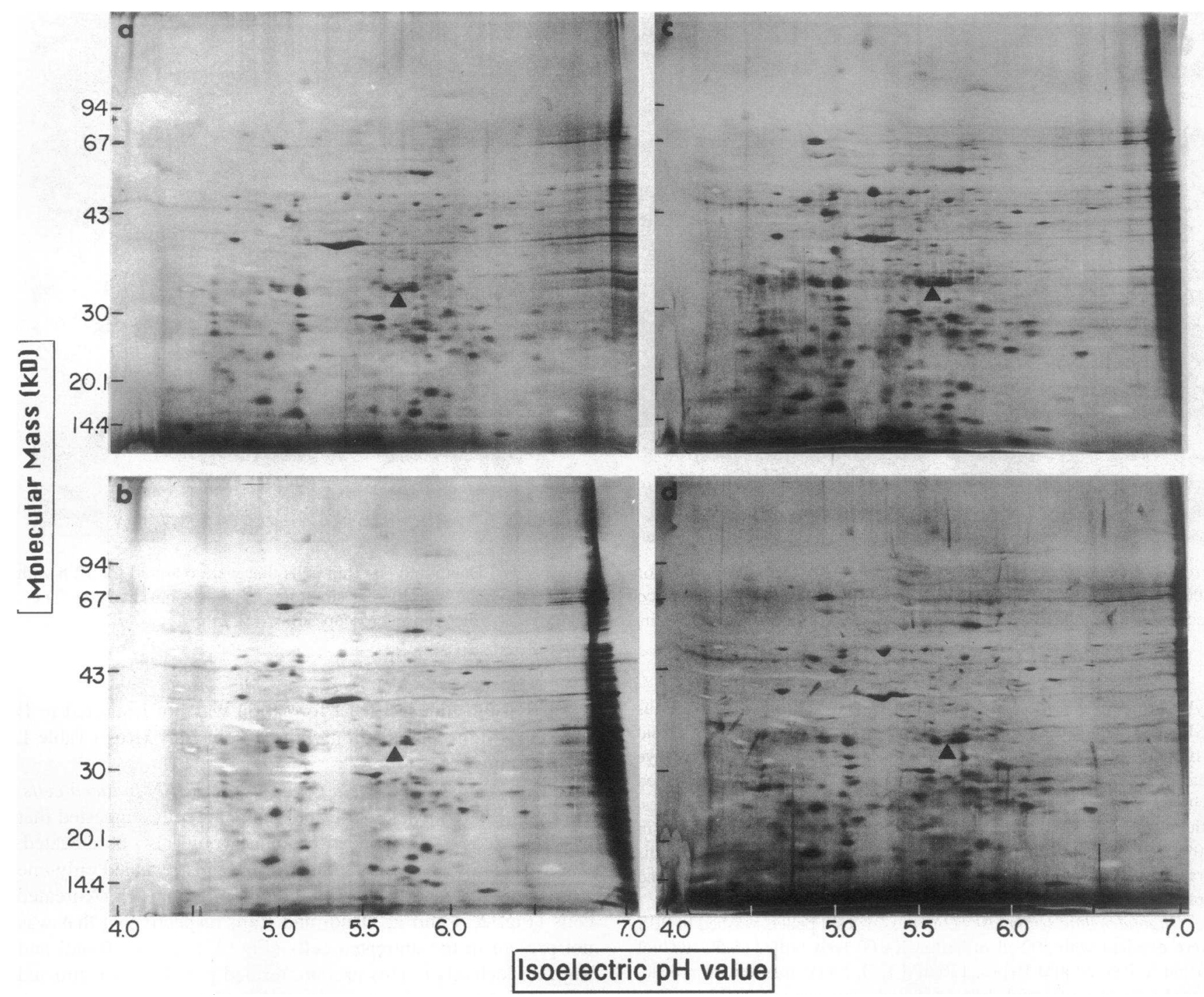

Figure 2. Two-dimensional polyacrylamide gel electrophoresis maps of Daudi $(a, b)$ and Raji $(c, d)$ cells after $(a, c)$ and before $(b, d)$ culturing for $72 \mathrm{~h}$ with $100 \mathrm{U} / \mathrm{ml}$ of IFLrA. p36 was detected only after IFLrA treatment $(a, c)$. Each sample consists of $400 \mu \mathrm{g}$ of total cell protein. Molecular masses and isoelectric points are noted on the vertical and horizontal axes, respectively. Silver staining was used because it is more sensitive than Coomassie brilliant blue, and it preferentially enhances p36 relative to the surrounding proteins.

to die by $48 \mathrm{~h}$, which increased to $100 \%$ by $120 \mathrm{~h}$. Both the LI and $\mathrm{p} 36$ protein were apparent throughout the $120 \mathrm{~h}$ time period of continued presence of $\alpha$-IFN. In Raji cells $\alpha$-IFN induced the p36 protein by $12 \mathrm{~h}$, and the LI by $24 \mathrm{~h}$ (Fig. $3 \mathrm{~b}$ ). They were present throughout the $168 \mathrm{~h}$ of $\alpha$-IFN treatment. Unlike Daudi cells, Raji cell growth and viability were unaffected by IFLrA. By $48 \mathrm{~h}$ after the removal of $\alpha$-IFN the p36 protein was no longer detected, and the inclusions were reduced to the very low frequency of $1.25 \%$. The essentially same time courses of appearance of p36 and LI upon $\alpha$-IFN stimulation of Daudi and Raji cells, and disappearance upon removal of $\alpha$-IFN with Raji cells, provide additional evidence for the association of p36 with LI.

Localization of lupus inclusions and the $p 36$ protein in cell fractions. Purified nuclei from IFLrA-induced Raji cells were prepared with nonionic detergent buffer (Fig. $4 a$ ). The LI from these cells were identified only in the cytoplasmic supernatant (Fig. $4 b$ ). Fractionation in the absence of nonionic detergents produced nuclei that contained a large amount of cytoplasmic membrane and LI (Fig. $4 c$ ). The LI were also located in the corresponding cytoplasmic fraction from these nuclei (Fig. 4 d). Two-dimensional gels showed the presence of $\mathrm{p} 36$ protein in the one nuclear (Fig. $4 c$ ) and two cytoplasmic (Fig. $4 b$ and d) fractions that contained LI. No p36 was apparent in the nuclear pellet without LI that was prepared with the nonionic detergent (Fig. $4 a$ ).

Secretion of $p 36$ protein. Two-dimensional gels of radiolabeled proteins released into the media by Raji cells revealed that p36 protein was secreted by the IFLrA-treated cells (Fig. $5 a$ ), but not by the untreated cells (Fig. $5 b$ ). Specificity for the proteins being secreted $\left(16.1 \%\right.$ of incorporated $\left[{ }^{3} \mathrm{H}\right]$-amino acids) was shown by comparison with $\left[{ }^{3} \mathrm{H}\right]$ thymidine and $\left[{ }^{3} \mathrm{H}\right]$ - 
Table II. Formation of p36 in Selected Cell Lines

\begin{tabular}{|c|c|c|c|c|c|c|}
\hline \multirow[b]{2}{*}{ Cell lines } & \multicolumn{3}{|c|}{ p36 Protein* } & \multicolumn{3}{|c|}{ Oligoadenylate synthetase ${ }^{t}$} \\
\hline & IFLrA & $\boldsymbol{\gamma}$ & o & IFLxA & $\gamma$ & o \\
\hline Daudi & + & - & - & 6177 & 1428 & 888 \\
\hline Raji & + & - & - & 4157 & 1252 & 721 \\
\hline SB & - & - & - & 2147 & 1472 & 375 \\
\hline HSB2 & - & - & - & 1065 & 185 & 90 \\
\hline MOLT & - & - & - & 1052 & 456 & 233 \\
\hline RAMOS & - & - & - & 2378 & 1023 & 203 \\
\hline AW RAMOS & - & - & - & 1687 & 843 & 188 \\
\hline
\end{tabular}

* The presence $(+)$ or absence $(-)$ of p36 was determined on silverstained two-dimensional gels run with $400 \mu \mathrm{g}$ of each cell line before (0), and after culturing for $72 \mathrm{~h}$ with $100 \mathrm{U} / \mathrm{ml}$ of IFLrA (e.g., Fig. 2, $a$ and $b$ for Daudi and Raji, respectively) or $\gamma$-IFN. ${ }^{\ddagger}$ Oligoadenylate synthetase assay values are reported as pmol of ATP hydrolyzed per 1 $\times 10^{5}$ cells (see Oligoadenylate synthetase assay, Methods) before (O) and after culturing for $72 \mathrm{~h}$ with $100 \mathrm{U} / \mathrm{ml}$ of IFLrA or $\gamma$-IFN.

uridine ( 2.6 and $1.6 \%$, respectively). No differences were obtained for the amount of secreted radiolabel between the IFLrAinduced and untreated cells.

The chase medium was also examined on two-dimensional gels from the other six cell lines listed in Table II. Daudi, like Raji, secreted p36 in chase medium only after IFLrA treatment. None of the other five cell lines showed the presence of p36 either with or without IFLrA treatment.

De novo synthesis of p36 protein. Raji cells were radiolabeled with [ ${ }^{35} \mathrm{~S}$ ] methionine for $18 \mathrm{~h}$ (one population doubling), chased for $6 \mathrm{~h}$, and cultured for an additional $18 \mathrm{~h}$ in the presence of $100 \mathrm{U} / \mathrm{ml}$ of IFLrA. However, p36 was not detected in an autoradiograph of these cells (Fig. $6 a$ ), which indicated that $\mathrm{p} 36$ was not formed from proteins synthesized before IFLrA addition. Yet p36 was detected in autoradiographs of aliquots of these same cells when pulsed at the times of 2 (Fig. $6 \mathrm{~b}$ ) and 18 (Fig. $6 c$ ) h after the addition of IFLrA. This showed that these cells were actively synthesizing p36 at this time. Thus p36 was synthesized de novo in response to IFLrA, and not from modifications to proteins that were synthesized before the addition of IFLrA.

\section{Discussion}

This study demonstrated that in Raji and Daudi cells $\alpha$-IFN induces $\mathrm{LI}$ in association with a $36-\mathrm{kD}$ protein with an isoelectric point of 5.6. Only these 2 cell lines, among 19 tested (Table I), formed LI to high frequencies and p36 to detectable levels (Fig. 1, Table II). The association of $\mathrm{p} 36$ protein with LI was further demonstrated by cell line responses to $\alpha$ - and $\gamma$-IFNs (Table II), by timecourse studies with the addition and removal of $\alpha$-IFN to Raji and Daudi cell cultures (Fig. 3), and by their codistribution in nuclear and cytoplasmic fractions of Raji cells (Fig. 4). Raji cells were also shown to synthesize p36 de novo (Fig. 6), like LI (10).

p36 was not detected in cell lines with low LI frequencies. This was probably due to the two-dimensional gel assay's relatively low sensitivity. LI frequency is the ratio of the LI to cell diameter (1). An LI frequency of $10 \%$ describes $2.0-\mu \mathrm{m} \mathrm{LI}$ in $20-\mu \mathrm{m}$ cells $(2.0 \mu \mathrm{m} / 20 \mu \mathrm{m})$, and $\mathrm{LI}$ of $0.4 \mu \mathrm{m}$ in the same diameter cell gives a $2 \%$ frequency $(0.4 \mu \mathrm{m} / 20 \mu \mathrm{m})$. Twodimensional gels measure the relative concentration of cell proteins, a volumetric relationship. Assuming that p36 is an LI component, its trace presence in Raji and Daudi cells (at $10 \%$ or greater LI frequency) indicates that at $2 \% \mathrm{LI}$ or less (Table I) p36 would not be detected [1/125th the amount $(0.4 \mu \mathrm{m} / 2.0$ $\mu \mathrm{m})^{3}$ ].

This analysis of other cell lines that didn't form LI above a $2 \%$ frequency concurred with no p36 detected in Raji cells with a $<2 \%$ frequency of $L I$ at $48 \mathrm{~h}$ after the removal of IFLrA (Fig. $3 \mathrm{~b}$ ). In contrast, the addition of IFLrA to both Raji and Daudi cells induced p36 before the formation of LI (Fig. $4 a$ at $6 \mathrm{~h}$, and Fig. $4 b$ at $12 \mathrm{~h}$ ). The subsequent exponential increase in LI frequency suggested the accumulation of a critical amount of LI precursors before the formation of the unique LI structure, and that p36 might be such a precursor.

LI are known to be disparate from an antiviral state since they do not form in WISH and MDBK cells with $\alpha$ - and $\gamma$ IFN treatment (22). P36 differs from most other reported IFNinduced proteins $(23,24)$ since it is not induced by $\gamma$-IFN (Table II, 4 ), and it is undetectable without $\alpha$-IFN treatment (Figs. $2 b$ and $d, 5 b$, and $6 a$ ).

Rapid secretion of p36 could explain its absence from cell lines without LI. In cells with LI, p36 might indicate an inhibition of this rapid secretion. However, p36 was not secreted
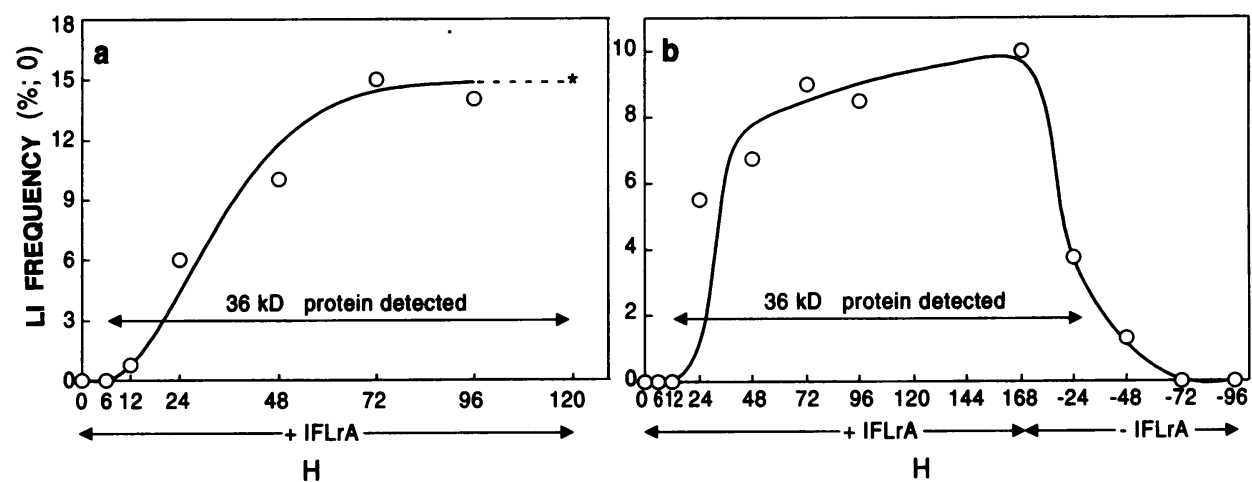

fected. The time course of disappearance of p36 and LI began at $168 \mathrm{~h}$ with the removal of IFLrA. The asterisk in $(a)$ denotes the detection, but not quantitation, of LI in deteriorating Daudi cells.
Figure 3. Time course of IFLrA $(100 \mathrm{U} / \mathrm{ml})$ induction of $\mathrm{p} 36(\leftarrow-\rightarrow)$ and LI $(O)$ in Daudi $(a)$ and Raji (b) cells. p36 is indicated as detectable or absent from two-dimensional gels of corresponding time point samples. LI frequency was the percentage of 400 independent cell sections examined that contained an LI (see EM enumeration of LI; Methods). In contrast to the complete IFLrA killing of the Daudi cell culture by $120 \mathrm{~h}$ (\% nonviable cells of 9,54 , 86 , and 100 at $48,72,96$, and $120 \mathrm{~h}$, respectively), Raji cells were unaf- 

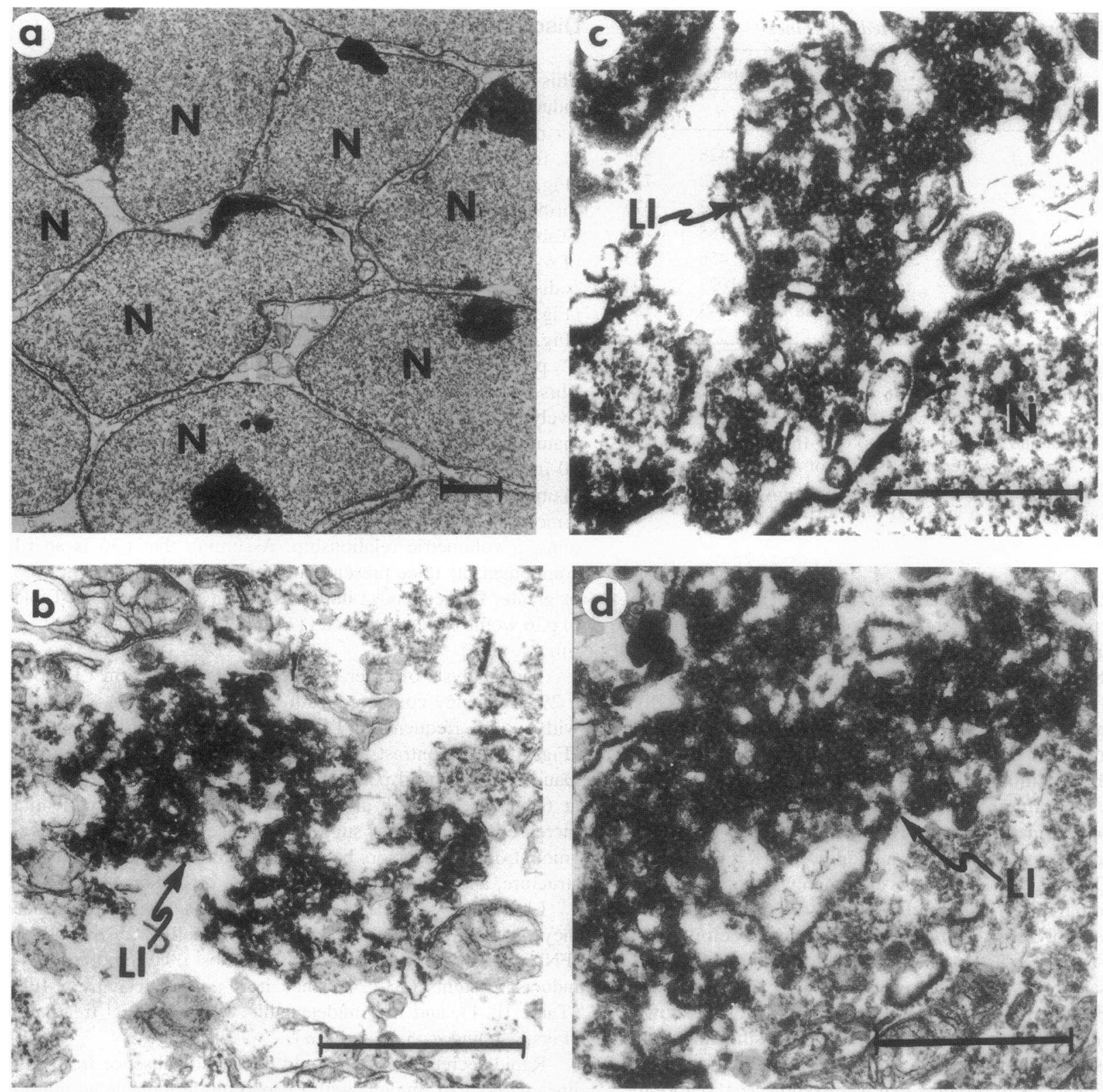

Figure 4. Fractionation of p36 with LI. Nuclear $(a, c)$ and cytoplasmic $(b, d)$ fractions of $72 \mathrm{~h} \mathrm{IFLrA-induced} \mathrm{(} 100 \mathrm{U} / \mathrm{ml})$ Raji cells were prepared with the low ionic strength buffer reticulocyte standard buffer in the presence $(a, b)$ and absence $(c, d)$ of the nonionic detergent Tween $40(0.1 \%$, $\mathrm{wt} / \mathrm{vol})$. N, nucleus. LI distribution was estimated from the average number of LI per grid square in the nuclear, and cytoplasmic ( $8,000 \mathrm{~g}$ for 20 $\mathrm{min}$ ), pellets. With Tween 40 all LI were in the cytoplasmic fraction ( $b$; e.g., no LI were detected in the corresponding nuclear pellet, $a$ ). Without Tween 40 LI distribution was approximately equal between the nuclear $(c)$ and cytoplasmic $(d)$ fractions. p36 was identified only in the three fractions in which the LI were present $(b-d)$. Electron micrographs are of thin sections $(0.1 \mu \mathrm{m})$ that were stained with uranyl acetate and lead citrate, and examined in a Philips 301 electron microscope. Bar $=1 \mu \mathrm{m}$.

either in the absence or presence of $\alpha$-IFN by cell lines without LI, and it was among Raji and Daudi cell-secreted proteins upon $\alpha$-IFN treatment (Fig. 5). The $<3 \%$ of thymidine and uridine detected in aliquots of these samples in contrast to the $16 \%$ of ${ }^{3} \mathrm{H}$ amino acids indicates specificity for protein secretion, and shows that LI did not inhibit it. LI formation in a restricted endoplasmic reticulum region that makes contact with the adjacent outer nuclear envelope and Golgi apparatus (11) suggests LI's role in protein synthesis and secretion which may include $\mathrm{p} 36$.
The $\alpha$-IFN-activated intracellular pathway consists of the nuclear translocation of three cytoplasmic proteins ( $p 84, p 91$, and p113) after their phosphorylation at specific tyrosine residues, their combining with a nuclear resident protein (p48), and transcriptional activation of $\alpha$-IFN-specific genes (25). Cell activation by $\gamma$-IFN involves the phosphorylation of the $91-\mathrm{kD}$ cytoplasmic resident protein, which forms a dimer, translocates to the nucleus, and activates $\gamma$-IFN-specific genes (26). Alphaand not $\gamma$-IFN induction of LI and p36 suggests involvement of the $\alpha$-IFN-activated intracellular pathway in these cells (4). 


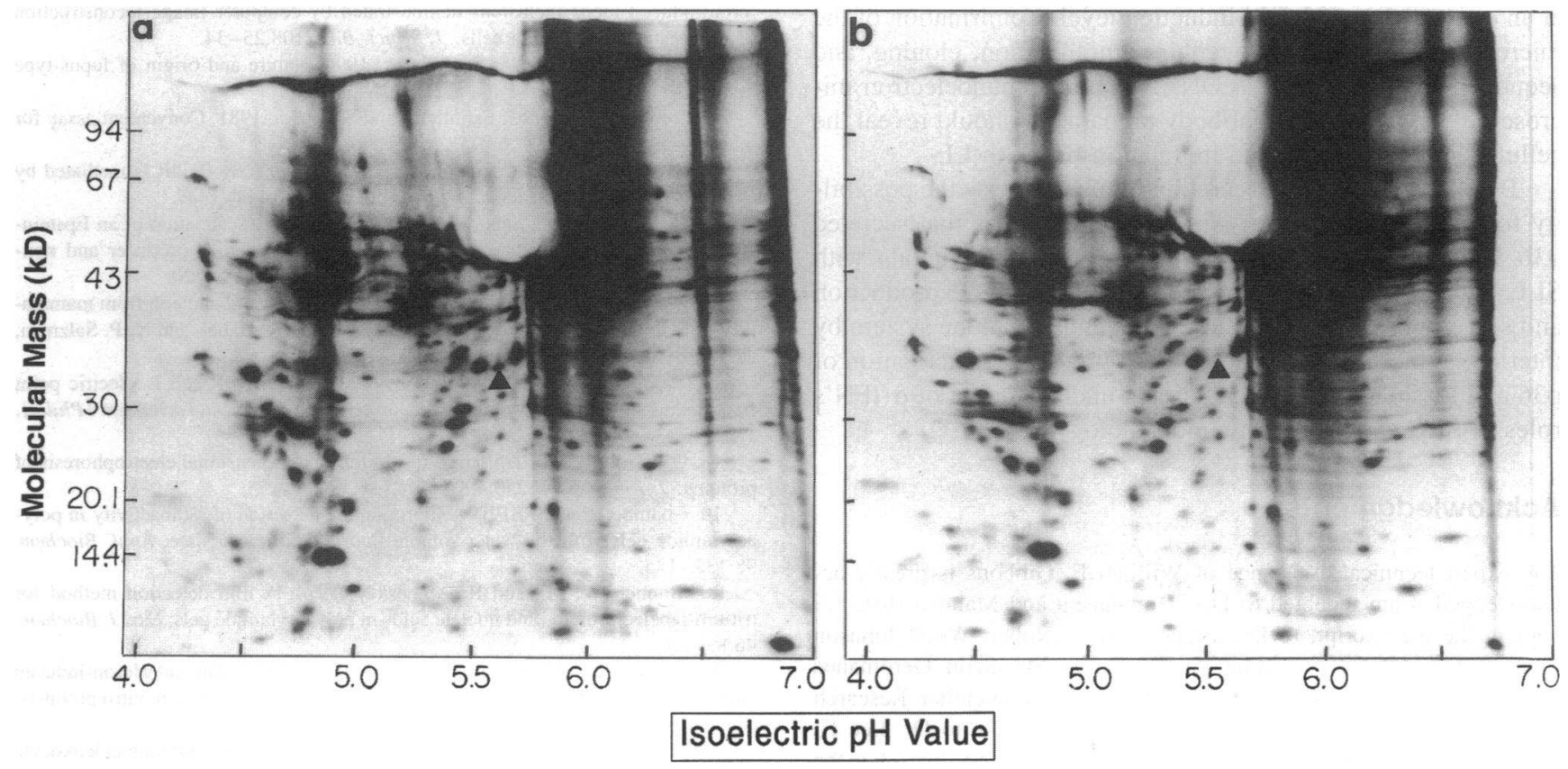

Figure 5. Two-dimensional gel autoradiographs of proteins secreted by Raji cells treated with $100 \mathrm{U} / \mathrm{ml}$ of IFLrA for $72 \mathrm{~h}(a)$, and not treated with IFLrA $(b)$. p36 was secreted only by Raji cells after IFLrA treatment $(a)$, but not in the proteins secreted by untreated Raji cells $(b)$. In both samples the amounts of ${ }^{3} \mathrm{H}$-amino acids $\left(16.1 \%\right.$ of the total incorporated during the pulse), or $\left[{ }^{3} \mathrm{H}\right]$ thymidine $(2.6 \%)$ or $\left[{ }^{3} \mathrm{H}\right]$ uridine $(1.6 \%)$ measured in the secretory medium were the same. The approximately eightfold greater release of protein over DNA and RNA demonstrates a selective secretion of protein, and p36 by $\alpha$-IFN-treated cells.

LI and p36 could be relevant to $\alpha$-IFN's immune modulatory effects (27-29). Two-dimensional gels of $\alpha$-IFN-induced human lymphoblastoid $(30,31)$ or peripheral blood mononuclear $(32,33)$ cells reveal a protein with p36's approximate molecular mass and isoelectric point. LI, $\gamma$-IFN, cell fractionation and secretion of proteins were not investigated in these studies. Daudi but not Raji cells were included in the lymphoblastoid studies $(30,31)$, and therefore it appeared that the $\alpha$-IFNinduced protein changes were associated with Daudi cell's severe growth inhibition and death (Fig. $3 a$ ).
With silver staining p36 is visible in whole cell samples (Fig. $2 a$ and $c$ ), and with Coomassie brilliant blue upon enrichment. This indicated that $\mathrm{p} 36$ was a candidate protein for purification and further characterization $(17,34,35)$. Tryptic peptide microsequence of purified p36 did not share any significant sequence identity with proteins listed in the SWISS-PROT (Geneva, Switzerland) data base, suggesting that it is a new protein (Rich, S. A., unpublished results). Anti-peptide antiserum prepared against p36 synthetic peptides has detected p36 protein in Western blots of Raji cells only after IFLrA induction, and
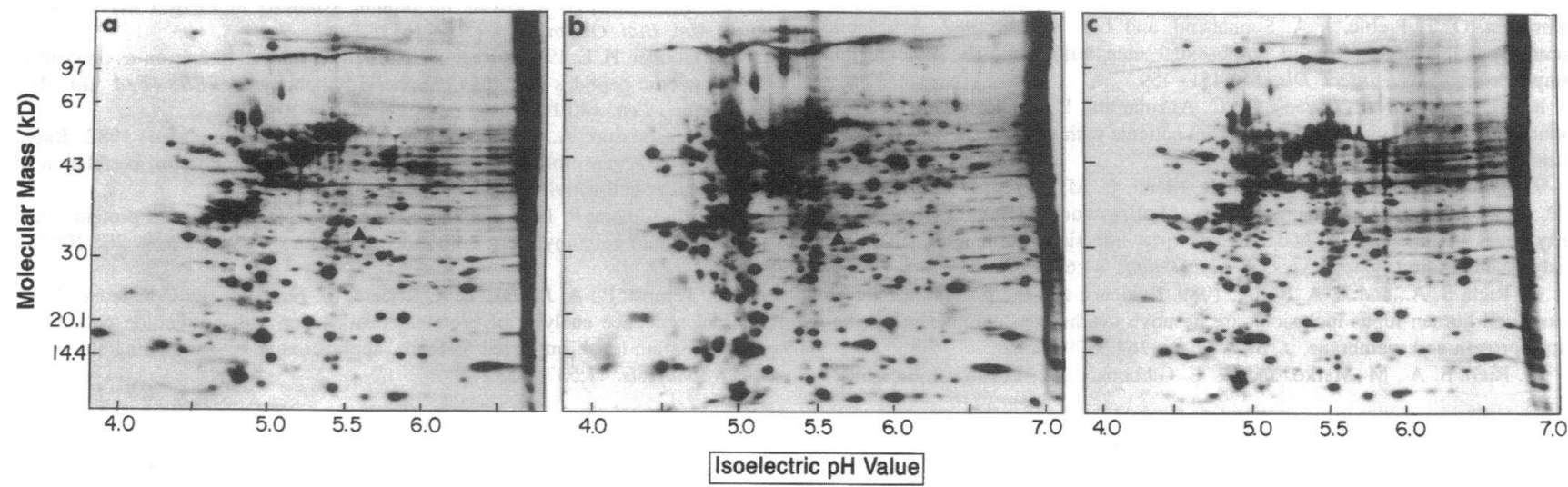

Figure 6. Two-dimensional gel autoradiographs of Raji cell proteins. Raji cells were radiolabeled with $\left[{ }^{35} \mathrm{~S}\right]$ methionine for $18 \mathrm{~h}$ (one population doubling), chased for $6 \mathrm{~h}$, and cultured for $18 \mathrm{~h}$ with $100 \mathrm{U} / \mathrm{ml}$ of IFLrA $(a)$. Aliquots of these same cells were radiolabeled for $40 \mathrm{~min}$ after culturing for $2(b)$ and $18(c) h$ with IFLrA. Together these results showed that p36 was not formed from proteins synthesized (radiolabeled) before the addition of IFLrA $(a)$, and its synthesis after $2(b)$ and $18(c)$ h of IFLrA treatment was a de novo response to IFLrA. 
at an estimated $>400$-fold induction level. Confirmation of the microsequence results will require amplification, cloning, and sequencing of p36 mRNA cDNA. In situ immunoelectron microscopy with a suitable antibody preparation should reveal the cellular location of p36 and its relationship with LI.

$\mathrm{B}$ cell production and secretion of $\mathrm{p} 36$ suggests the possibility for interleukin activity. Another possibility is that secreted p36 induces autoantibodies. Thus $\alpha$-IFN in individuals with SLE and AIDS could stimulate LI formation and $\mathrm{p} 36$ production and secretion. Also, p36 could modulate the immune system by interleukin or autoantigen activities. Further characterization of p36 and LI should provide additional understanding of $\alpha$-IFN's roles in SLE and AIDS immunopathology.

\section{Acknowledgments}

The expert technical assistance of William E. Gibbons is greatly acknowledged. I am indebted to Drs. Himangshu and Mahuya Bose for reading the manuscript, to Dr. Sidney Pestka (Robert Wood Johnson Medical School) for providing the IFLrA, to Mr. Scott Geromanos (Sloan-Kettering Institute for Cancer Research, Rockefeller Research Laboratories) for the microsequencing of purified p36, to Dr. Lee $\mathrm{H}$. Kronenberg (Lee Biomolecular Research Laboratories) Inc.) for the LUK II and 8866.7 cell lines, and to Dr. Julius Youngner (School of Medicine, University of Pittsburgh) for the RAMOS and AW RAMOS cell lines.

This work was supported by a grant from the National Institutes of Health (AR 41619 to S. A. Rich).

\section{References}

1. Rich, S. A. 1981. Human lupus inclusions and interferon. Science (Wash. DC). 213:772-775.

2. Gyorkey, F., K.-W. Min, J. G. Sinkovics, and P. Gyorkey. 1969. Systemic lupus erythematosus and myxovirus (letter). N. Engl. J. Med. 280:333.

3. Orenstein, J. M., G. L. Simon, C. M. Kessler, and R. S. Schulof. 1985 Ultrastructural markers in circulating lymphocytes of subjects at risk for AIDS Am. J. Clin. Pathol. 84:603-609.

4. Rich, S. A., T. R. Owens, L. E. Bartholomew, and J. U. Gutterman. 1983. Immune interferon does not stimulate formation of alpha and beta interferon induced human lupus-type inclusions (letter). Lancet. i:127-128.

5. Rich, S. A., and W. E. Gibbons. 1990. Human lupus-type inclusions in umbilical cord blood mononuclear cells. Arthritis Rheum. 33:1420-1425.

6. Preble, O. T., R. J. Black, R. M. Friedman, J. H. Klippel, and J. Vilcek. 1982. Systemic lupus erythematosus: presence in human serum of an unusual acid-labile leukocyte interferon. Science (Wash. DC). 216:429-431.

7. De Stefano, E., R. M. Friedman, A. E. Friedman-Kien, J. J. Goedert, D. Henriksen, O. T. Preble, J. A. Sonnabend, and J. J. Vilcek. 1982. Acid-labile human leukocyte interferon in homosexual men with Kaposi's sarcoma and lymphadenopathy. J. Infect. Dis. 146:451-459.

8. Rich, S. A., T. R. Owens, M. C. Anzola, and L. E. Bartholomew. 1986. Induction of lupus inclusions by sera from patients with systemic lupus erythematosus. Arthritis Rheum. 29:501-507.

9. Feremans, W. W., K. Huygen, R. Menu, C. M. Farber, J. P. DeCaluwe, J. P. VanVooren, L. Marcelis, L. Andre, M. Brasseur, H. Bondue et al. 1988. Fifty cases of human immunodeficiency virus infection: immunoultrastructural study of circulating lymphocytes. J. Clin. Pathol. 41:62-71.

10. Rich, S. A., and A. A. Reilly. 1989. Evidence that the interferon-induced Daudi cell human lupus inclusions are de novo synthesized complexes of ribonucleoprotein and membrane. J. Biol. Chem. 264:3529-3537.

11. Rich, S. A., M. Marko, and W. E. Gibbons. 1992. Localization of inter- feron-induced lupus inclusions demonstrated by computer image reconstruction of monensin-treated Daudi cells. J. Struct. Biol. 108:25-34.

12. Rich, S. A., and W. E. Gibbons. 1990. Nature and origin of lupus-type inclusions (letter). Hum. Pathol. 21:1191-1192.

13. Rubinstein, S., P. C. Familletti, and S. Pestka. 1981. Convenient assay for interferons. J. Virol. 37:755-758.

14. Rich, S. A. 1981. Induction of lupus inclusions by BUdR is mediated by a human lymphoid cell factor. Arthritis Rheum. 24:1444-1447.

15. Reedman, B. M., and G. Klein. 1973. Cellular localization of an EpsteinBarr virus (EBV)-associated complement-fixing antigen in producer and nonproducer lymphoblastoid cell lines. Int. J. Cancer. 11:499-520.

16. Penman, S. 1969. Preparation of purified nuclei and nucleoli from mammalian cells. In Fundamental Techniques in Virology. K. Habel, and N. P. Salzman, editors. Academic Press, New York. 35-48.

17. Rich, S. A., and W. E. Gibbons. 1989. ROTOFOR cell isoelectric point fractionation of detergent solubilized protein cell samples. Technique (Phila.). 1:196-203.

18. O'Farrell, P. H. 1975. High resolution two-dimensional electrophoresis of proteins. J. Biol. Chem. 250:4007-4021.

19. Chamberlain, J. P. 1979. Fluorographic detection of radioactivity in polyacrylamide gels with the water-soluble fluor, sodium salicylate. Anal. Biochem. 98:132-135.

20. Bonner, W. M., and R. A. Laskey. 1974. A film detection method for tritium-labeled proteins and nucleic acids in polyacrylamide gels. Eur. J. Biochem. 46:83-88.

21. Merlin, G., M. Revel, and D. Wallach. 1981. The interferon-induced enzyme oligo-isoadenylate synthetase: rapid determination of its in vitro products. Anal. Biochem. 110:190-196.

22. Rich, S. A., and T. R. Owens. 1984. Purified recombinant human leukocyte interferons IFLrA and IFLrD induce human lupus inclusions in Raji and Daud cells. J. Interferon Res. 4:335-345.

23. Beresini, M. H., M. J. Lempert, and L. B. Epstein. 1988. Overlapping polypeptide induction in human fibroblasts in response to treatment with interferon-alpha, interferon-gamma, interleukin 1-alpha, interleukin 1-beta, and tumor necrosis factor. J. Immunol. 140:485-493.

24. Sen, G. C., and R. M. Ransohoff. 1993. Interferon-induced antiviral actions and their regulation. In Advances in Virus Research. K. Maramorosch, F. A. Murphy, and A. Shatkin, editors. Academic Press, San Diego. 57-102.

25. Shuai, K. 1994. Interferon-activated signal transduction to the nucleus. Curr. Opin. Cell Biol. 6:253-259.

26. Shuai, K., G. R. Stark, I. M. Kerr, and J. E. Darnell, Jr. 1993. A single phosphotyrosine residue of STAT91 required for gene activation by interferongamma. Science (Wash. DC) 261:1744-1746.

27. Holan, V., S. Nakamura, and J. Minowada. 1992. Inhibitory versus stimulatory effects of natural human interferon-alpha on proliferation of lymphocyte subpopulations. Immunology. 75:176-181.

28. Bloom, B. R. 1980. Interferon and the immune system. Nature (Lond.) 284:593-596.

29. Herberman, R. B., J. R. Ortaldo, and G. D. Bonnard. 1979. Augmentation by interferon of human natural and antibody-dependent cell-mediated cytotoxicity Nature (Lond.). 277:221-223.

30. Guardini, M. A., M. P. Schoenberg, R. B. Naso, B. A. Martin, J. U. Gutterman, and J. Guevara, Jr. 1984. Induction of proteins in human lymphoblastoid cells by recombinant alpha interferon. J. Interferon Res. 4:67-79.

31. Leanderson, T., S. Sundstrom, I.-L. Martensson, T. Ny, and E. Lundgren 1982. Interferon-specific effects on protein synthesis in $\mathrm{P}_{3} \mathrm{HR}-1$ cells. EMBO (Eur. Mol. Biol. Organ.) J. 1:1505-1511.

32. Cooper, H. L. 1982. Effect of bacterially produced interferon- $\alpha_{2}$ on synthesis of specific peptides in human peripheral lymphocytes. FEBS (Fed. Eur. Bio chem. Soc.) Lett. 140:109-112.

33. Gustafsson, A., S. Sundstrom, T. Ny, and E. Lundgren. 1982. Rapid induction of seven proteins in human lymphocytes by interferon; correlation to natural killer cell activity. J. Immunol. 129:1952-1959.

34. Matsudaira, P. 1987. Sequence from picomole quantities of proteins electroblotted onto polyvinylidene difluoride membranes. J. Biol. Chem. 262:1003510038.

35. Tempst, P., A. J. Link, L. R. Riviere, M. Fleming, and C. Elicone. 1990 Internal sequence analysis of proteins separated on polyacrylamide gels at the submicrogram level: improved methods, application and gene cloning strategies. Electrophoresis. 11:537-553. 